\title{
Effects of Gmelina aborea fruit juice on histopatholology of cardiac muscle, gills, liver and skin of Clarias gariepinus juveniles
}

\begin{abstract}
Aquaculture has led to increases in fish consumption despite the fact that feral fish stock is biologically over fished. Aquaculture of species like Clarias gariepinus is contributing to this increased fish consumption, especially in Nigeria as it is the major cultured fish. This work aimed at investigating the effects of Gmelina arborea fruit juice on the Histopathology of the fishes' heart, gills, liver and skin. Observations showed that the fruit juice was able to stretch the myocyte of the heart leading to the disintegration of the cardiac muscle tissue. In the gills, there was congestion of the blood vessels and erosion of the epithelial cells, leading to complete damage. There was equally erosion of the dermal tissue. Vacuolation occurred in the hepatocytes and congestion of the blood vessels. All these histopathological events may have caused fish mortality. The observed $\mathrm{LC}_{50}$ of the fish 24, 48, 72 and 96 hours was 223, 213, 175 and 155 respectively. Giving that Gmelina arborea is capable of producing a large number of fruits that usually fall on the ground, it is not advisable to site fish pond in the Gmelina plantation.
\end{abstract}

Keywords: gmelina aborea, histopatholology, clarias gariepinus juveniles
Volume 7 Issue 4 - 2018

\section{Fidelis Bekeh Ada}

Department of Fisheries and Aquatic Science, Cross River University of Technology, Nigeria

Correspondence: Fidelis Bekeh Ada, Department of Fisheries and Aquatic Science, Faculty of Agriculture and Forestry, Cross River University of Technology, Obubra Campus, Nigeria, $\mathrm{Tel}+2348068546835,+2347088237937$

Email fbekehada@yahoo.com, fidekisa@gmail.com

Received: July 04, 2018 | Published: August 10, 2018

\section{Introduction}

As feral fish stock is dwindling, ${ }^{1}$ there is a need to culture fish in guided aquatic environments free of hazards, in agricultural plants plantations and in homesteads. As it is observed, Aquaculture has become a sure way of replacing the natural stock ${ }^{2}$ especially from inland waters that are in affinity with anthropogenic influence. ${ }^{3,4}$ This redirection of effort from capturing to culturing fish has led fish consumption per person per yearto increase over time. ${ }^{2}$ The average person now eats roughly 44 pounds $(19.96 \mathrm{Kg})$ of fish per year compared to only 22 pounds $(9.98 \mathrm{Kg})$ in the $1960 \mathrm{~s}$. This is irrespective of the fact that the world population has $251.64 \%$ increase $(3,033,212,527$ in 1960 to $7,632,819,325$ in 2018) within this period.

According to a report, people now consume more farmed fish than wild-caught fish for the first time. Yet, fish from natural marine resources are still being overharvested at biologically unsustainable levels, ${ }^{2}$ maintained.

In aquaculture environments, there is usually a site selection that requires a consideration of some criteria. Siting a pond in areas where natural toxins from plants products introduce toxin into water should be avoided. For instance, it was observed that saw dust, bark and other parts of Piptadeniastrum africanum could distort the normal physiology of fish. ${ }^{6,7,8}$

Gmelinaarborea though not indigenous to Nigeria, is well adapted to Nigerian environmental conditions ${ }^{9,10}$ It has so many uses to man including its values for timber and medicine. ${ }^{11}$ The roots, fruits and the leaves of Gmelina arborea has great medicinal value therefore traditionally, it is widely used as anthelmintic, antimicrobial, antidiabetic, anti-aging, analgesic, diuretic, hepato-protective and antiepileptic agent. ${ }^{12}$ From the review of Kulkami et al., ${ }^{13}$ it could treat all illnesses. It has rapid growth, and maximum economic returns. The Gmelina arborea wood is used for pulp, particle board, plywood, matches, carpentry and packing. It is also used for construction of boards, carving and musical instruments. ${ }^{11}$
The leaves and fruits of Gmelina arborea are used as fodder, and also used for rearing silkworms. The species are also planted as a shade tree for coffee and cocoa. A lot of work has been done on its value in human medicine ${ }^{14}$ little or no information is available on the effects of Gmelina arborea on fish. There is also a vast amount of work on plants extracts and agro chemicals on the haematology, ${ }^{15,16}$ histopathology ${ }^{17,18}$ oxidative stress, serum chemistry of fish and mammals. ${ }^{14,19-22}$ Therefore, the present study was designed to examine the effects of its fruit juice on the Histology of a widely culture fish, Clariasgariepinus. The fish is hardy in both culture and laboratory work. Nasar et al., in $\mathrm{FAO}^{23}$ describe it as equivalent of the guinea pig in aquatic environment; while ${ }^{23}$ described it as equivalent of the cockerel of poultry industry. This is because, lot of water bodies inhabited by fish co-exist in the plantations. The need to site fish culturing facility devoid of hazards has been emphasised by Kovari and Elekes. ${ }^{25,26}$

\section{Materials and methods}

Mature fruits of Gmelina arborea that were ripped and had fallen to the ground were picked from the Gmelina Forest of Forestry and Wildlife Management Department of Cross River University of Technology, Obubra Campus. The fruits were massaged and pressed with fingers to expel a dark black juice. One litre quantity of the juice was collected for use. The juice was measured in $\mathrm{ml}$ to constitute the concentration in $\mathrm{ml} / \mathrm{L}$ (ppt) for the experiment. Therefore, concentration of $0.0 \mathrm{ml} / \mathrm{L}, 100 \mathrm{ml} / \mathrm{L}, 200 \mathrm{ml} / \mathrm{L}, 300 \mathrm{ml} / \mathrm{L}, 400 \mathrm{ml} / \mathrm{L}$, $500 \mathrm{ml} / \mathrm{L}$ and $600 \mathrm{ml} / \mathrm{L}$ respectively of Gmelina fruit juice were constituted for the range finding experiments and $58 \mathrm{mg} / \mathrm{L} 117 \mathrm{mg} / \mathrm{L}$, $175 \mathrm{mg} / \mathrm{L}, 223 \mathrm{mg} / \mathrm{L} 293 \mathrm{mg} / \mathrm{L}$, and $350 \mathrm{mg} / \mathrm{L}$ for the definitive experiments. Results of range finding experiments were not reported here but were used to estimate the highest concentration $(\mathrm{ml} / \mathrm{L})$ of juice to be used during the definitive test of 96 hours.

Ten fish were randomly selected and stocked in each concentration, replicated in triplicate. ${ }^{26,27}$ The fish stocked were $915.7 \pm 30.3$ mgand169.7 $\pm 11.1 \mathrm{~mm}$ sourced from Cross River University of 
Technology Fish Farm in Obubra local government of Cross River State.

The fish were observed for behavioural and biological characters. Frequency of observation was at short intervals from the beginning (every 30 minutes) and less frequent towards the end (one hourly and much later, every 12 hourly).Biological observations from here were recorded in Table 1, which shows the LC50 at different times. The LC50 was estimated using probit, a graphical method. During the experiment, water quality parameters such as water temperature, dissolved oxygen, $\mathrm{pH}$, conductivity and transparency were monitored. Water temperature was measured using mercury in glass thermometer graduated in degree Celsius (0C). Dissolved oxygen was measured using 970 JENWAY DO2 meter (made by BIBBY scientific Ltd., UK) to the nearest $0.1 \mathrm{mg} / \mathrm{L}$. The $\mathrm{pH}$ was measured using 3505 JENWAY (made by BIBBY scientific Ltd., UK) while the Conductivity was measured using a DDS-307 conductivity meter

After 96 hours of exposure, the exposed fish were dissected to remove the liver, skin, gills and kidney for processing. These were processed in Histopathology, laboratory of Teaching Hospital of University of Calabar. The tissues were dehydrated using ascending grades of ethanol $(70 \% .90 \%$ absolute $1,2,3)$ to remove water for
30 minutes, cleared through two (2) charges of xylene $(1,2)$ for 30 minutes. The tissues were impregnated with molten puraffin wax. Two (2) changes were used to ensure proper impregnation for 30 minutes. These were embedded and sectioned (3-4 $\mu \mathrm{m}$ thin) using rotary microtone. Staining was carried out using Haematoxylin and Eosin after de-waxing in different grades of alcohol. ${ }^{28}$ The slides were cleared in xylene and mounted with D. P.X Mountant. A high Definition (H D) microscope was used to take the picture (Leica DFC495 attached to a Leica M205C on a XYstage and LED5000 MCI illumination, Germany). One way analysis of variance was used to determine the differences between water quality parameters. Duncan multiple range test was used to separate the means. ${ }^{8}$

\section{Results}

The LC50for one day, one and half days, two days and four days were shown in Table 1. The table also show the save concentrations for different periods calculated from the formula of Koesomadinata. ${ }^{28}$ The histopathological sections of the heart, gills, liver and skin are displayed on Figure 1-4 respectively. The water quality parameters were not statistically different among treatments except the conductivity. Though there was observed absolute variation among these parameters namely, temperature, $\mathrm{pH}$ and dissolved oxygen.

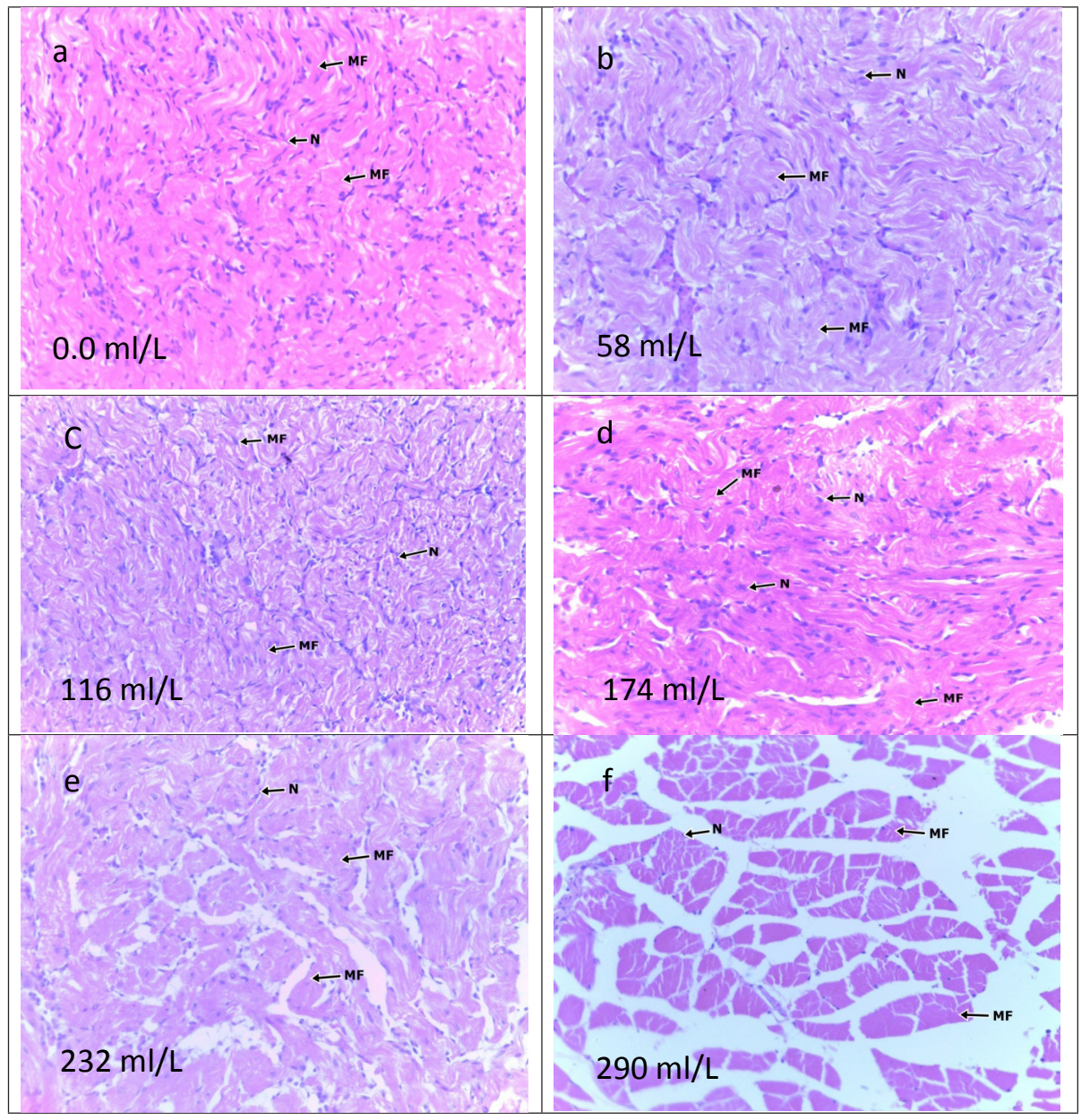

Figure I Sections of the cardiac muscle of Clarias garipinus exposed to Gmelina arborea fruit juice: (a) intact cardiac myocytes that are plump and having oval deeply stained sparsely populated nuclei, (b) the intervening blood vessels are congested, (c) the intervening fibrocollagenous stroma is thin (d) individual cardiac myocytes are stretched out with abundant cytoplasm and round to oval shaped muscle, the blood vessels are congested, (e) overall disintegration of the cardiac tissue ( $f$ ) total disintegration of the cardiac muscle tissue. 


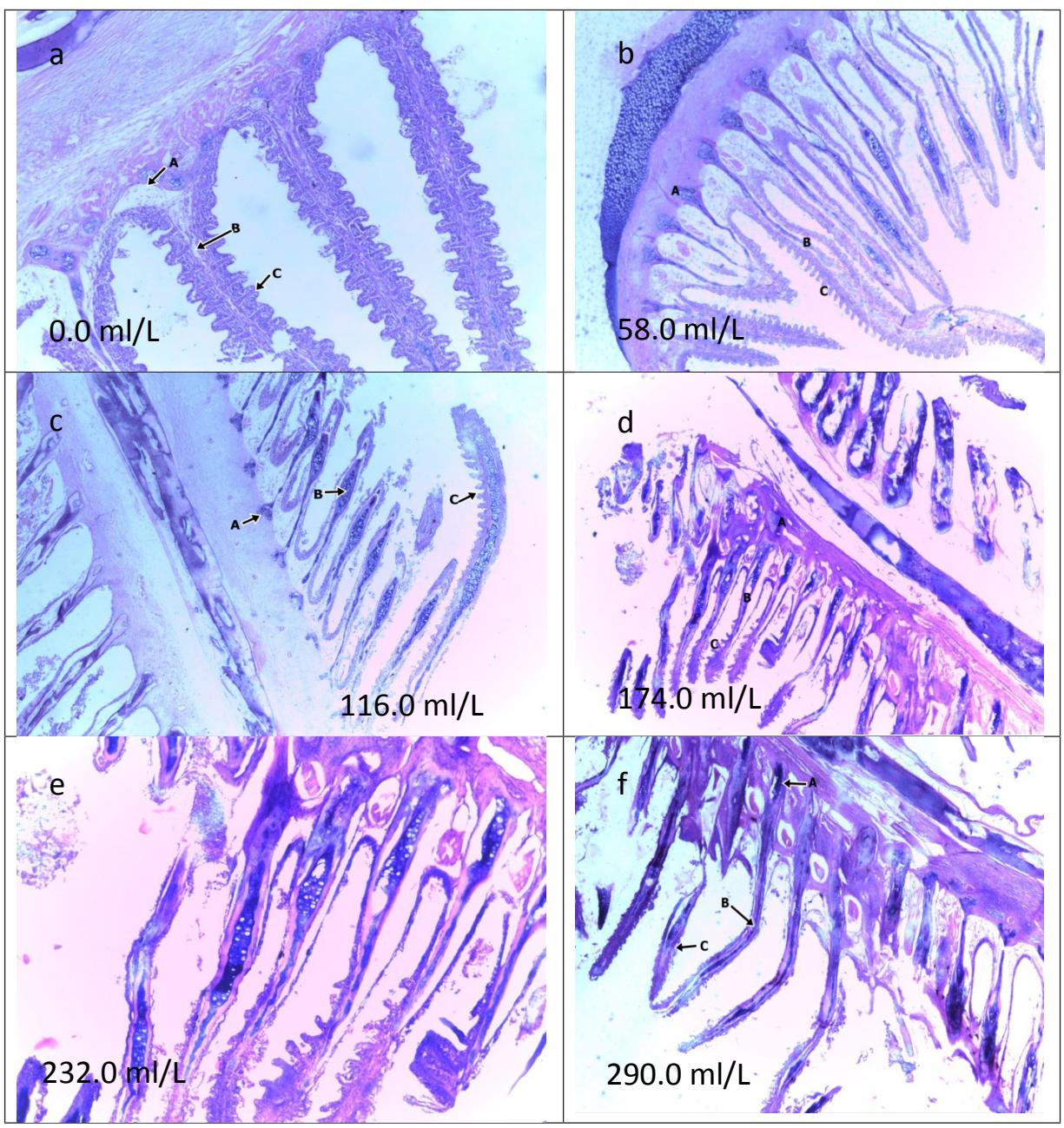

Figure 2 showing Sections of the gills Clariasgarieoinus exposed to Gmelinaarboreafruit juice: (a) there are prominent gill arches with distinct primary and secondary lamellae, the secondary lamellae have vascular middle core with epithelial cells on both side. (b) has gill arch (A) with distinct primary lamellae(B) The epithelium is mildly ulcerated and there are prominent congested blood vessels and proliferating pillar cells.(c) erosion of the secondary epithelial cells. (d) Erosion of the epithelial cells (e) There are congested blood vessels and proliferating pillar cells with epithelium grossly damaged (f) erosion leading to complete breakage of the filaments.

\section{Discussion}

It is recorded widely in literature that Gmelina arborea is medicinal, capable of curing illness in man including worm expulsion, microbial infection, diabetic, aging, analgesic, diuresis, hepatic disorders and epileptic $^{11,}$ The fruit juice of this plant was seen to cause mortality in Clarias gariepinus at concentration of $223 \mathrm{ml} / \mathrm{L}$ and $155 \mathrm{ml} / \mathrm{L}$ within 24 hours and 96hours respectively. Though fish and man are both vertebrates, they seem to react differently to different parts of this plant. The plant which was said to bring about wound healing in man, is seen here to cause erosion in gills and skin of Clarias gariepinus (Figures 1) (Figures 4) respectively). However over doses of all medicines are likely to become poison to the organism which the medicine was meant to treat. That is why the safe concentration were estimated using a formula proposed by Keosomadinata ${ }^{28}$ as in Table 1.

Phytochemical profiling carried out by Anjaneyulu \& Hosny et al., ${ }^{30,31}$ revealed that the plant juice has flavonoids, iridoid glycosides(twelve acylatediridoidglycosides), and lignans.
Hydroxylignans is from heart wood, ${ }^{14}$ pointed that these substances are capable of changing the physiological state of an organism. In appropriate concentrations, these phytochemicals act as antioxidants. They have been found useful in the management of diabetes. ${ }^{21}$ In consideration of Gmelina arborea for drugs preparation for fish, concentrations recorded as safe concentration in Table 1 could be used. At higher concentration such as those that kill the fish here, they were able to damage all the tissues investigated. These include the heart, liver, gills and skin. However, there are no records of such damage in mammals.

All the tissues investigated were affected by the fruit juice. These form important organs of vertebrates' body. At sublethal concentration of $1 \mathrm{ppm},{ }^{32}$ found that there was increased formation of Malondialdehydes in the liver, kidney, gills and heart of Clariasgariepinus on exposure to Butachlor. They also found increased superoxide dismutase and catalase activities in the liver and kidney while activities of these enzymes were reduced than normal in the gills and heart. 


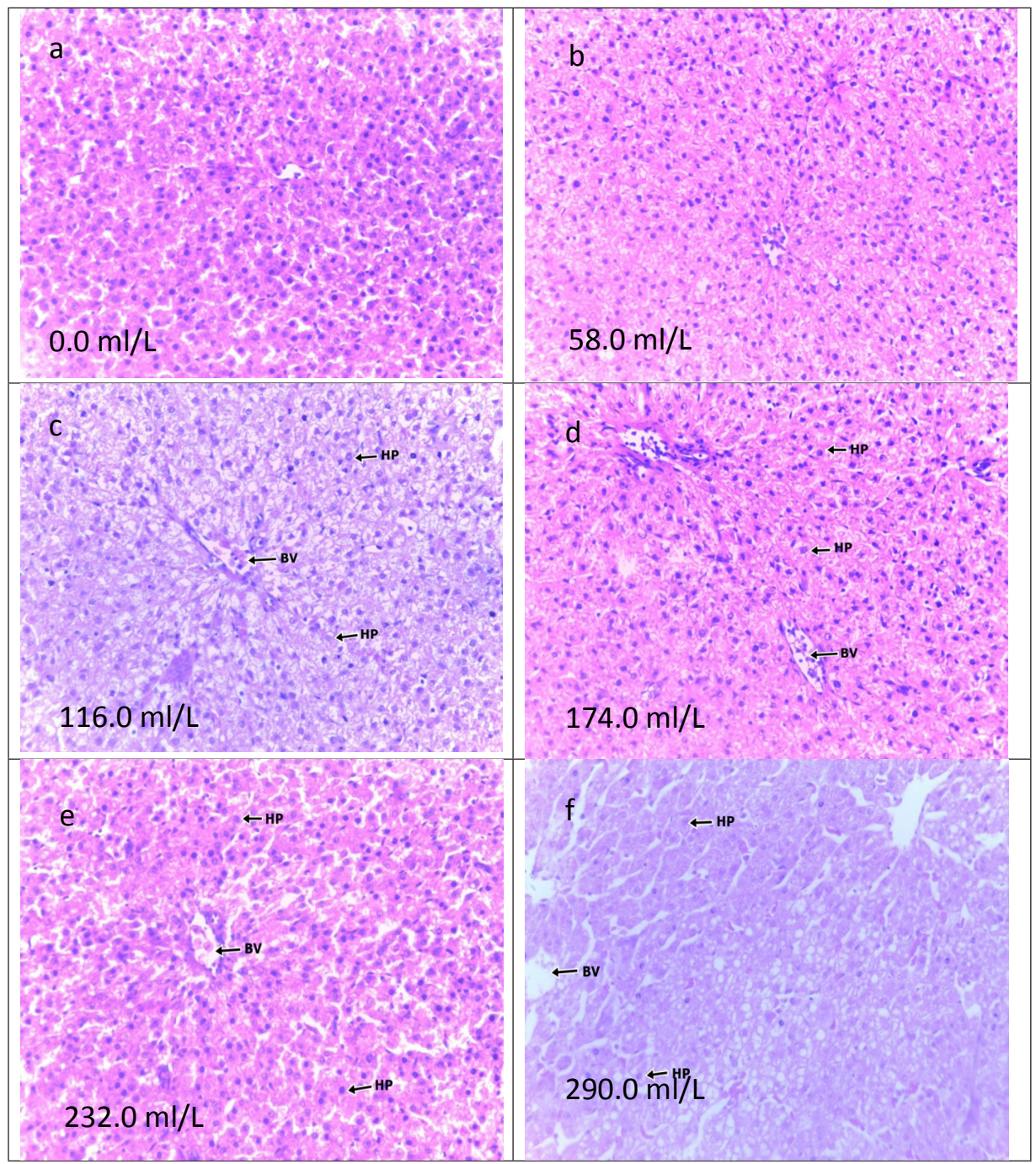

Figure 3 showing liver sections of Clariasgariepinus exposed to Gmelina arborea fruit juice (a) normal hexagonal liver lobules separated by sinusoidal spaces located between the polygonal hepatocytes. (b)The sinusoidal spaces are narrowed and the blood vessels are congested. (c) The hepatocytes have moderate amount of granular cytoplasm with mild vacuolations and prominent centrally located nuclei having fine chromatin pattern. (d) The hepatocytes display extensive irregular vacuolations. (e) The spaces are lined by endothelial cells and there is moderate amount of sinusoidal inflammation. (f) The hepatocytes display extensive irregular vacuolations. The sinusoidal spaces are narrowed and the blood vessels are dilated and congested.

The heart is known to be the main organ of circulation. Failure of this pumping organ mean there is failure in the distribution of food substances and oxygen to the body because these substances are carried by the blood. Waste products also have to be removed by the blood. ${ }^{33}$ The main point of entry of oxygen to the body is gills. These were eroded. Their function of absorbing dissolved oxygen from the water cannot be efficient in this state of damage. ${ }^{34}$ The skin is the gate way that selects substances that passes in and out of the fish through it. In a damaged state, substances pass in and out uncontrolled. Similarly, the liver is an organ responsible for detoxification. With the liver damaged, normal physiological reactions cannot be carried out. . $^{34,35-38}$ Water quality parameters were within the acceptable range for the normal survival of this species. Conductivity that vary equally remain within normal range for fish as Fondriest ${ }^{33}$ pointed out that conductivity for fish survival has a wide range of values with no particular value regarded as the most acceptable for all organisms(Table 2).
Table I The $\mathrm{LC}_{50}$ of Gmelinaaborea fruit juice on Clariasgariepinus juvenile and safe concentrations for different periods

\begin{tabular}{llll}
\hline S/N & HOURS & LC50 & $\begin{array}{l}\text { Safe concentration } \\
=\text { LC }_{50} \times 0.01-0.1\end{array}$ \\
\hline 1 & 24 & 223 & $2.23-22.3$ \\
2 & 36 & 213 & $213-21.3$ \\
3 & 48 & 193 & $1.933-19.3$ \\
4 & 72 & 175 & $1.75-17.5$ \\
5 & 96 & 155 & $1.55-15.5$ \\
\hline
\end{tabular}


Table 2 Physicochemical properties of water exposed to different concentrations of Gmelina fruit juice during toxicity assay of Clariasgariepinus

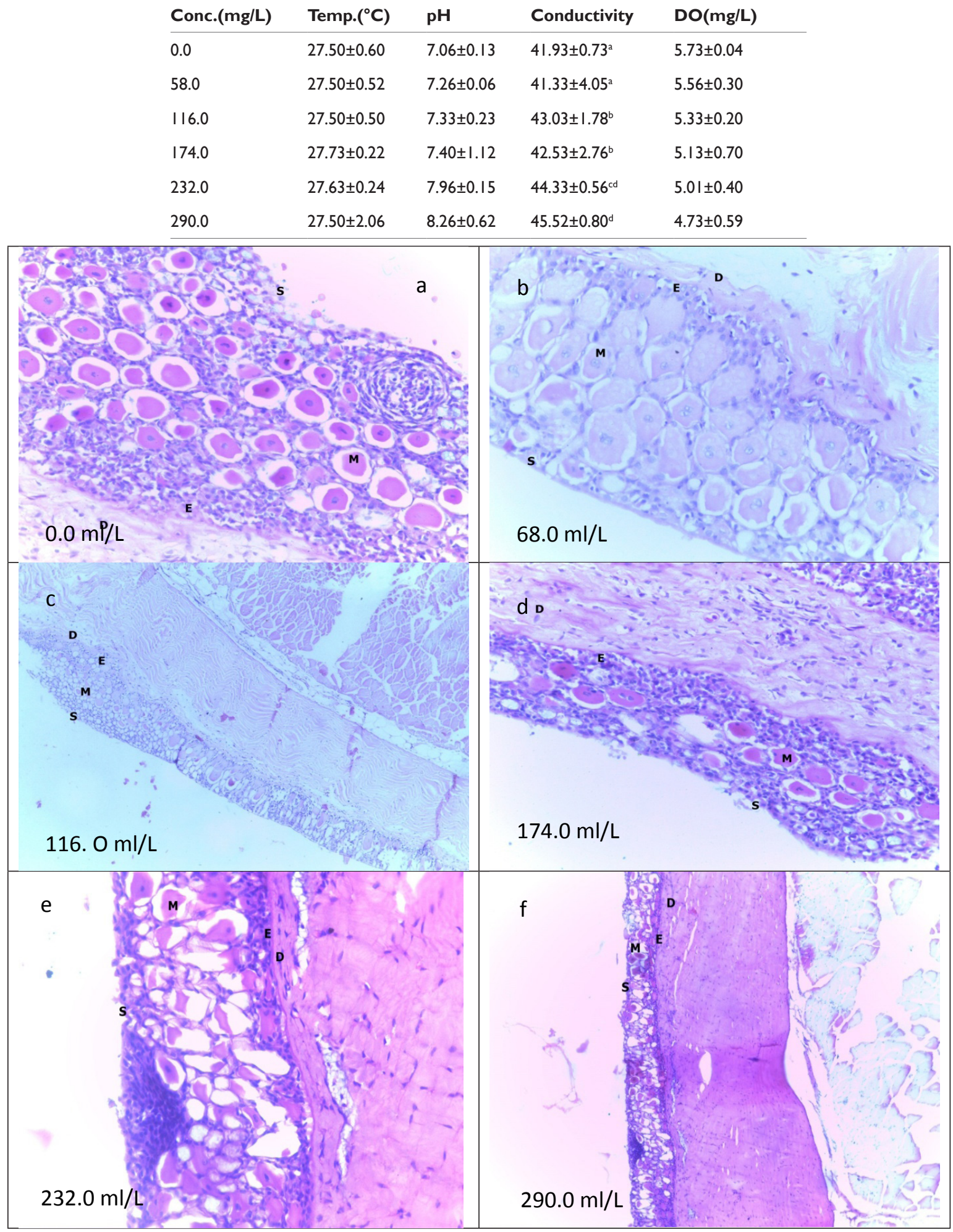

Figure 4 is made of sections of the skin of Clariasgariepinus exposed to Gmelina arborea fruit juice (a). The mucus-secreting cells are prominent and scanty goblets cells found, lymphocytes and macrophages are seen. The dermis is dense consists of bundles of collagenous tissues, scattered fibroblasts, and few pigment cells. S-superficial mucin, M-mucus cells, E- sub-epidermal layer, D- Dermis. (b) vaculations in the dermal region. (c)The proximal epidermal cells have vacuolated cytoplasm. The mucus-secreting cells are prominent but few and scanty goblets, lymphocytes and macrophages are seen. (d)The mucus secreting cells are abundant and prominent. (e)The dermis is dense and comprised of fibro-collagenous fibres, fibroblasts and scanty inflammatory cells. (f) The mucus-secreting cells are prominent and abundant and severe inflammatory infiltrates mainly lymphocytes and sprinkling of inflammatory cells. 


\section{Acknowledgements}

I am grateful to Mr Stanley Agianpuye Ushie for taking data as an under graduate candidate and partially funding this work; and also Mr Canice Adie Agogo of the Histopathology Laboratory, Teaching Hospital, University of Calabar, Nigeria for Processing and interpreting the slides for this research work.

\section{Conflict of interest}

None.

\section{References}

1. FAO. United Nations Food and Agriculture Organization. General situation of world fish stocks FAO's report. Review of the State of World Marine Fisheries Resources. 2018

2. Eco Watch. Global Fish Stocks Depleted to ‘Alarming’ Levels. 2018.

3. Adeyemo OK. 2003. Consequences of Pollution and Degradation of Nigeria Aquatic Environment on Fisheries Resources. Environmentalist. 2003;23(4):297-306

4. Cengiz EI, Unlu E, Balci K. The Histopathological Effects of Thiodin on the liver and gut of mosquito fish, Gambusiaafinis. Journal of Environmental Science and Health, 2001;36(1):75-85.

5. Worldometer. Population of Nigeria: 2018 and historical. 2018

6. Ada FB, Ekpenyong E, Ekpali ME. Histopathological observations in gut of Clariasgariepinus juveniles exposed to aqueous extract of Piptadeniastrumafricanum bark. International Journal of Innovative Agriculture \& Biology Research. 2016;4(3):26-38.

7. Ada FB, Ayotunde EO, Mgbongo M. The haematological response of Clariasgariepinus juvenile exposed to aqueous bark extract of Piptadeniastrumafricanum. International Journal of Innovative Studies in Aquatic Biology and Fisheries. 2017;3:(1):23-32.

8. Ayotunde EO, Ada FB, Bassey UP. Toxicity of Small Leaf Piptadeniastrum africanum (Saw- Dust Powder) to African Catfish, Clariasgariepinus, Adults. Journal of Fisheries and Aquaculture Development. 2017.

9. Greenland Government, 2018. Weeds of Australia.

10. PROTA. Gmelina arborea. Plant Resources of Tropical Africa. 2018.

11. Vikaspedia. Gmelina aeborea. 2018.

12. Herbpathy. Gmelina herb uses, benefits, cure, side effects, nutrients

13. Kulkarni YA, Patel RV, Tawade A, et al. Effect of Gmelinaarborea Roxb in experimentally induced inflammation and nociception. Journal of Ayurveda Integr Meddcine.2013;4(3):152-157.

14. Sinha S. Bark and Fruit Extracts of Gmelinaarborea. Protect Liver Cells from Oxidative Stress. Pharmaceutical Biology. 2008; 44(4): 237-243.

15. Ayotunde EO, Ada FB, Ogbeche LO. Haematological and Histopathological Responses of Catfish Clariasgariepinus Juvenile to Coconut Water Cocosnucifera. Journal of Fisheries and Aquatic Studies. 2015;3(1): 97-110.

16. Deshmukh DR. Hamatological response in a freshwater fish Channa Striatus exposed to endosulfanpesticide. Bioscience Discovery. 2016;7(1):67-69.

17. Basker T. Impact of nitrate toxicity on histopathological profile to freshwater fish, Cirrhinusmrigala. International Journal of Engineering and Science. 2014;5(4):42-47.
18. Samanta P, Sandipan P, Mukkherjee KA, et al. The effects of Almix herbicide on histopathological and ultrastructural alterations in fresh water fish, Heteropneustesfossilis: A comparative study. Annals of Biological Research, 2016;7(2):24-32.

19. Kasperska-Zajac A, Brzoza Z, Rogala B, et al. 2008. Antioxidant Enzyme Activity and Malondialdehyde Concentration in the Plasma and Erythrocytes of Patients With Urticaria Induced by Nonsteroidal Antiinflammatory Drugs. Journal of Investigative Allergoly and Clinical Immunology. 2008;18(5):372-375.

20. Kulkarni. Toxicological studies on aqueous extract of Gmelina arborea in rodents. Pharmaceutical Biology. 2010;48(12).

21. Kulkarni YA, Veeranjaneyulu A. Effects of Gmelina arborea extract on experimentally induced diabetes. Asian and Pacific Journal of Tropical Medicine. 2013;6(8):602-608.

22. Ateufact G, Domgnim EC, Mbiantcha MM, et al. Gastroprotective and ulcer healing effects of piptadeniastrum Africanum on experimentally induced gastric ulcers in rats. BMC Complementary and Alternative Medicine. 2015.15:214

23. FAO. Commercial value of African catfish (Clarias gariepinus, Burchell), Food and Agricultural Organisation of the United Nations. 2002.

24. Agbo AD. Nigeria: Why Nigerian Fish Farmers Neglect Tilapia Daily Trust of March, 10, 2016, Abuja Nigeriaallafrica.com. 2016.

25. Kövári J. Considerations in the Selection of Sites for AquacultureIn.Food and Agriculture Organization of the United Nations Rome, Italy. 2018.

26. Elekes K. Principles of Designing Inland Fish Farms In Food and Agriculture Organization of the United Nations Rome, Italy. 2018.

27. APHA. American public health association standard method for examination of water and wastewater. 13th Edn. ALPHA Washington DC. USA. 1998; 1254 p.

28. Oti EE. Upkabi UH. 2000. Acute toxicity of milk extract of Thevetiaperuviannato African catfish (hubrids). Afican. Journal of Science and Technology. 2000;1:132-138.

29. Ajiboye TO, Ahmad FM, Daisi AO. Hepatoprotective potential of Phyllanthusmuellarianus leaf extract: studies on hepatic, oxidative stress and inflammatory biomarkers. 2017.

30. Anjaneyulu ASR, Madhusudhana RA, Kameswara RV, et al. 1977. Novel hydroxylignans from the heartwood of Gmelina arborea. Tetrahedron. 1977;33(1):133-143.

31. Hosny M, Rosaazza JPN, Gmelinosides AL. Twelve acylatediridoid glycosides from Gmelina arborea. Journal of Natural Product. 1998;61:734-742.

32. Farombi EO, Ajimoko YR, Adelomo OA. Effect of Butachlor on anti oxidant enzyme status and lipid perioxidation in fresh water African catfish (Clariasgariepinus). International Journal of Environmental Research and Public Health. 2008;5(5):423-427.

33. Taylor DJ, Green NPD, Stout GW. Biological science, R. stopper edition. Cambridge university press. 1998. 983p.

34. Langiano Vdo C, Martinez CB, Toxicity and effects of a glyphosate-based herbicide on the Neotropical fish Prochilodus lineatus. Comparative Biochem and Physiology. 2007;147(2):222-231.

35. Stehr CM, Johnson LL, Myers MS. Hydropic vacuolation in the liver of three species of fish from the U.S. West Coast: lesion descriptionand risk assessment associated with contaminant exposure. Diseases of aquatic organisms. 1998;32:119-137. 
36. Fondriest Environmental. Conductivity, Salinity and Total Dissolved Solids. Fundamentals of Environmental Measurements. Web.2014.

37. Idodo-Umeh G, Oronseye JAO. Heavy Metal Pollution in Ololomoro, Niger Delta, Nigeria. Journal of Fisheries.2006;3(2):267-279.
38. Introduction to herbal medicine. 2008. 